\title{
PENGENALAN PERMAINAN WARNA MELALUI KONSEP SENYAWA POLAR DAN NON POLAR
}

\author{
Fikri Nazarullail \\ Universitas Trunojoyo Madura \\ Email: fikrinazarullail@gmail.com \\ Dwi Bagus Rendy A.P \\ Universitas Trunojoyo Madura \\ Email: rendiradja@gmail.com
}

\begin{abstract}
Introduction to Color Games Through the Concept of Polar and Non Polar Compounds. This research was conducted to provide a new learning experience by adapting the concept of color recognition combined with simple science (polar and non polar). This study uses quantitative research approach with one-shot case study type. The results of a simple experimental process conducted in the learning process get positive data that is $88 \%$ or 15 children get a very good score and $12 \%$ or 2 children get a good score. Based on these results, similar activities can be carried out to introduce children to the concept of mixing colors adapting simple science in learning activities.
\end{abstract}

Key words: color games; color mixing; polar and non polar

\begin{abstract}
Abstrak: Pengenalan permainan warna melalui konsep senyawa polar dan non polar pada penelitian ini dilaksanakan untuk mengetahui kadar pengalaman belajar baru dengan mengadaptasi konsep pengenalan warna dipadukan dengan sains sederhana (polar dan non polar). Penelitian ini menggunakan pendekatan penelitian kuantitatif dengan jenis one-shot case study. Hasil dari dari proses eksperimen sederhana yang dilakukan pada proses pembelajaran mendapatkan data positif yaitu $88 \%$ atau 15 anak memperoleh skor sangat baik dan $12 \%$ atau 2 anak mendapatkan skor baik. Berdasarkan hasil tersebut maka kegiatan serupa dapat dilakukan untuk mengenalkan kepada anak tentang konsep pencampuran warna mengadaptasi sains sederhana dalam kegiatan pembelajaran.
\end{abstract}

Kata kunci: permainan warna; pencampuran warna; polar dan non polar

\section{PENDAHULUAN}

Anak merupakan individu yang lahir di dunia memiliki karakteristik tertentu yang khas dan tidak sama dengan orang dewasa, oleh karena itu mereka selalu aktif, dinamis antusias terhadap apa yang dilihat, didengar, dirasakan mereka seolah-olah tidak pernah berhenti untuk bereksplorasi. ${ }^{1}$ Menurut Kertamuda ${ }^{2}$ pada saat anak lahir masuk pada periode emas,

${ }^{1}$ Yuliani Nurani Sujiono. Konsep Dasar Pendidikan Anak Usia Dini. Jakarta: PT Indeks. 2012: 6 
Fikri Nazarullail, Dwi Bagus Rendy A.P, Pengenalan Permainan Warna Melalui Konsep Senyawa Polar dan Non Polar

dimana pada masa usia 0-8 tahun, anak masuk pada periode emas (golden age). Pada fase emas juga termasuk periode kritis karena menentukan pembentukan anak pada pertumbuhan dan perkembangan anak pada usia berikutnya. Orang tua memiliki tugas dan tanggung jawab untuk mengantarkan anak mencapai perkembangan yang terbaik.

Perkembangan pada anak usia dini merupakan perubahan yang terjadi secara kualitatif dimana terjadi perubahan mental yang berlangsung secara bertahap dalam kurun waktu tertentu, dari kemampuan yang sederhana menjadi kemampuan yang lebih terampil seperti kecerdasan, sikap, dan tingkah laku. ${ }^{3}$ Perkembangan bukanlah suatu perubahan yang terjadi secara berangsur-angsur yang tepas satu sama lain, tetapi terjadi karena satu rentetan yang tidak ada putusputusnya sehingga menjadi struktur yang semakin sempurna.

Dunia anak adalah bermain, oleh Karena itu aktivitas belajar untuk menstimulasi perkembangan anak. Anak akan secara suka rela melakukan aktvitas bermain dengan mengeksplorasi hal-hal yang ada di sekitarnya. ${ }^{4}$ Pendidik dapat menciptakan aktivitas belajar yang menyenangkan seperti mengadaptasi kegiatan bermain agar proses belajar menjadi lebih menarik dan menyenangkan. Hal tersebut sesuai dengan pernyataan Hurlock ${ }^{5}$ bahwa bermain merupakan kegiatan yang menyenangkan, dilakukan atas inisiatif sendiri serta bukan paksaan dari orang lain. Oleh karena itu proses belajar yang paling ideal bagi anak usia dini dilaksanakan dengan proses yang menyenangkan dengan bermain seraya belajar.

Belajar seraya bermain hendaknya selaras dengan terbentuknya stimulasi perkembangan anak. Stimulasi melalui bermain juga dapat

2 Miftahun Achyar Kertamuda. Golden Age: Strategi Sukses Membentuk Karakter Emas Pada Anak Sejak Usia Dini. Jakarta: PT Gramedia. 2015: 4

${ }^{3}$ Ahmad Susanto. Perkembangan Anak Usia Dini. Jakarta: Kencana. 2014: 21

4 lbid.

${ }^{5}$ Elizabeth Hurlock. Perkembangan Anak. Jakarta: Erlangga. 1978: 138 
bermanfaat untuk meningkatkan aspek perkembangan anak usia dini. Salah satu aspek perkembanganan anak usia dini yang dapat di stimulasi melalui kegiatan bermain adalah perkembangan kognitif. Kognitif atau sering dihubungkan dengan kecerdasan yang dimiliki oleh manusia dan merupakan kemampuan proses berfikir seseorang terhadap kejadian yang dialaminya. Dalam kata lain perkembangan kognitif ini merupakan kemampuan untuk mengasah keterampilan dan konsep baru, keterampilan untuk memahami apa yang terjadi di lingkungannya, serta daya ingat untuk menyelesaikan permasalahan-permasalahan sederhana. ${ }^{6}$ Perkembangan kognitif juga dimaksudkan agar anak mampu mengeksplorasi lingkungan sekitarnya melalui indera yang dimiliki.

Salah satu aktivitas bermain yang bisa di aplikasikan secara sederhana pada pembelajaran adalah dengan bermain. Menurut Emmy Budiartati $^{7}$ dalam artikel ilmiahnya menjelaskan bahwa bagi anak-anak bermain adalah kegiatan yang bersungguh-sungguh, melalui bermain anak menjelajahi dunianya dan memperoleh manfaat belajar sesuatu yang baru. Bermain bagi anak adalah suatu kegiatan yang bermakna. Bermain merupakan proses belajar dan cara untuk memperoleh pengetahuan tentang sesuatu, seperti warna, bentuk, dan bilangan. Melalui bermain juga dapat membantu anak untuk menstimulasi perkembangan kognitif seperti mengenalkan warna dan sains pada anak usia dini. Pembentukan pengetahuan anak dengan bermain dan dikombinasikan dengan praktikum sederhana akan berguna untuk menambah wawasan dan pengalaman kepada anak tentang ilmu pengetahuan alam.

Aktivitas belajar yang digemari oleh anak usia dini adalah mewarnai. Kegiatan mewarnai dapat menjadi media berekspresi anak,

${ }^{6}$ Fikri Nazarullail. Permainan Tradisional (Ditinjau dari Aspek Perkembangan Anak Usia Dini). Surabaya: Pondok Pesantren (Ponpes) Jagad 'Alimussirry. 2019: 24

${ }^{7}$ Emmy Budiartati. Pembelajaran Melalui Bermain Berbasis Kecerdasan Jamak Pada Anak Usia Dini. Jurnal Lembaran IImu Pendidikan. Jilid 38 No 2. 2008: 97 
Fikri Nazarullail, Dwi Bagus Rendy A.P, Pengenalan Permainan Warna Melalui Konsep Senyawa Polar dan Non Polar

dengan memilih warna-warna yang sesuai dengan keinginannya yang mungkin akan berbeda dengan pilihan temannya yang lain. ${ }^{8}$

Konsep pengenalan warna dapat dilakukan dengan berbagai macam aktivitas, salah satunya adalah bermain dengan menggunakan pendekatan ilmu pengetahuan alam/sains. Sujiono juga mengemukakan bahwa sains bagi anak usia dini akan membantu anak dalam mengembangkan aspek kognitifnya. ${ }^{9}$ Hal tersebut juga berhubungan dengan hasil penelitian terdahulu yang dikemukakan oleh Khairani Amalia bahwa melalui kegiatan eksperimen dapat meningkatkan kemampuan sains anak untuk mengenal benda cair. ${ }^{10}$ Pengenalan sains sederhana pada anak usia dini memang saat ini bukan menjadi hal yang sulit untuk diterapkan, karena pengenalan ilmu pengetahuan alam sederhana dapat menjadi alternatif baru untuk meningkatkan perkembangan kognitif anak dengan memanfaatkan kejadian secara alami atau eksperimen sederhana memanfaatkan bahan-bahan yang biasa ditemui dalam kehidupan seharihari.

Pengenalan sains sederhana kepada anak usia dini adalah dengan melakukan pencampuran warna dengan jenis ikatan kimia yang berbeda atau dalam bahasa ilmiahnya adalah senyawa polar dan non polar. Misal pada kegiatan bermain mengenal warna dengan melakukan pencampuran senyawa polar dengan senyawa non polar, maka akan terjadi dua lapisan senyawa yang tidak dapat bercampur. Jlka senyawa tersebut memiliki warna yang berbeda maka akan menghasilkan dua lapisan warna. Seperti air yang tidak berwarna di campur dengan minyak yang berwarna kuning. Pencampuran kedua senyawa tersebut juga bisa dilakukan dengan memanfaatkan dua atau lebih senyawa yang memiliki warna yang

${ }^{8}$ Nani Husnaini. Kegiatan Mewarnai Sebagai Stimulasi Perkembangan Kognitif Anak Usia Dini. Volume 3 No. 2. 2019: 112-133

9 ibid

10Khairani Amalia. Meningkatkan Kemampuan Sains Mengenal Benda Cair Melalui Metode Eksperimen. Jurnal IImiah Potensia. Vol. 3 No. 2. 2018: 8 
berbeda, sehingga pada saat proses eksperimen pencampuran warna dengan senyawa polar dan non polar akan menghasilkan tingkat warna yang berbeda.

Berdasarkan dari proses pengenalan sains sederhana pada kegiatan pembelajaran, melalui bermain pencampuran warna dengan senyawa polar dan non polar dapat menghasilkan pengetahuan kepada anak bahwa senyawa dengan jenis polar secara sederhana adalah cairan yang dapat larut jika dicampurkan dengan senyawa yang bersifat polar juga. Sebaliknya jika senyawa polar di campur dengan non polar maka tidak akan tercampur. Konsep tersebut dalam kimia dikenal dengan like dissolve like. Hal tersebut menjadi poin yang sangat penting karena dapat menjadi inovasi baru dalam kegiatan pembelajaran untuk meningkatkan perkembangan kognitif anak terhadap pencampuran warna dan senyawa kimia polar-non polar sederhana yang dapat ditemukan anak di lingkungan sehari-hari. Seperti yang sudah banyak diketahui bahwa biasanya guru hanya mengenalkan aktivitas pencampuran warna menggunakan pewarna makanan atau cat air.

\section{METODE PENELITIAN}

Penelitian ini menggunakan pendekatan kuantitatif berjenis eksperimen dengan desain one-shot case study. Dalam penelitian kuantitatif dilaksanakan dengan tujuan untuk menguji teori dengan analisis kuantitatif. ${ }^{11}$ Teknik pengumpulan data pada penelitian ini menggunakan angket dengan melakukan observasi secara langsung pada peserta didik dengan data cek lis. Angket disusun menggunakan skala likert agar mempermudah dalam melakukan analisis data. Teknik analisis data dilakukan secara kualitatif dengan mengelompokkan informasi-informasi dari data yang berupa respon pengetahuan anak dalam memahami pencampuran warna dan unsur polaritas. Hasil dari analisis data

\footnotetext{
${ }^{11}$ Aamin Silalahi. Metodologi Penelitian dan Studi Kasus. Jakarta: Citramedia. 2003
} 
Fikri Nazarullail, Dwi Bagus Rendy A.P, Pengenalan Permainan Warna Melalui Konsep Senyawa Polar dan Non Polar

menggambarkan persentasi hasil kegiatan polar dan non polar yang dilaksanakan pada anak usia dini.

Tujuan dari penelitian ini adalah untuk mengenalkan tentang pencampuran warna sederhana dan mengenalkan konsep polar dan non polar pada anak usia dini dengan memanfaatkan benda cair yang terdapat di sekitar lingkungan anak yang mudah ditemukan.

Penelitian ini akan menghasilkan nilai pemahaman anak tentang konsep pencampuran warna dengan senyawa polar dan non polar yang dapat diperoleh berdasarkan persamaan sebagai berikut.

$$
P=\frac{f}{N} \times 100 \%
$$

Keterangan:

$f=$ Jumlah skor pengumpulan data

$\mathrm{N}=$ Skor maksimal

$\mathrm{P}=$ Persentase validitas $^{12}$

Selanjutnya hasil dari perhitungan nilai pemahaman anak dianalisis dengan skala skor sebagai berikut: ${ }^{13}$

Tabel 1. Tabel skor data perhitungan nilai pemahaman anak

\begin{tabular}{lll}
\hline No. & Persentase & Kategori \\
\hline $\mathbf{1}$ & $100-81$ & SangatBaik \\
$\mathbf{2}$ & $61-80$ & Baik \\
$\mathbf{3}$ & $41-60$ & Cukup \\
$\mathbf{4}$ & $21-40$ & Buruk \\
$\mathbf{5}$ & $0-20$ & SangatBuruk \\
\hline
\end{tabular}

12 Purwanti Suci Muji Daryamti, Fitriani, \& Fadhilah, R. (2018). Pengembangan Lembar Kegiatan Peserta Didik (LKPD) Berbasis Predict-Observe-Explain (POE) pada Sub Materi Sifat Senyawa Ion dan Kovalen untuk Kelas X Farmasi SMK Panca Bhakti Sungai Raya. Ar-Razi Jurnal Imiah, Vol. 6(1), hal. 98-108. doi: http://openjurnal. unmuhpnk. ac. id/index. php/ar-r/article/download/947/736

${ }^{13}$ Riduan. 2009. Dasar-dasar Statistika. Bandung: Alfabeta 


\section{KERANGKA TEORI}

\section{Bermain Melalui Pengenalan dan Pencampuran Warna}

Bermain adalah kegiatan yang menyenangkan dengan tanpa mempedulikan hasil akhir. Bermain juga dilakukan atas inisiatif sendiri serta bukan merupakan kewajiban atau suatu paksaan dari orang lain. Menurut Battelheim adalah "kegiatan yang tidak memiliki aturan kecuali yang ditetapkan oleh pemain itu sendiri, dan tidak ada hasil akhir yang dimaksudkan dalam realitas luar". ${ }^{14}$ Bermain juga dapat dikombinasikan dengan kegiatan pembelajaran agar proses belajar di kelas menjadi lebih menyenangkan. Hal tersebut juga sejalan dengan hasil penelitian Hidayati yang mengemukakan bahwa kegiatan mencampur warna adalah hal yang menyenangkan dan dapat meningkatkan kemampuan mereka dalam memahami hasil dari pencampuran warna. ${ }^{15}$

Sujiono menjelaskan secara khusus tentang proses pembelajaran pada anak usia dini haruslah didasarkan prinsip-prinsip perkembangan anak usia dini, berikut ini:

a. Proses kegiatan belajar pada anak usia dini harus dilaksanakan berdasarkan prinsip belajar melalui bermain

b. Proses kegiatan belajar anak usia dini dilaksanakan dalam lingkungan yang kondusif dan inovatif baik di dalam ruangan ataupun di luar ruangan

c. Proses kegiatan belajar anak usia dini dilaksanakan dengan pendekatan tematik dan terpadu.

\footnotetext{
${ }^{14}$ Elizabeth Hurlock. Perkembangan Anak. Jakarta: Erlangga. 1978

${ }^{15}$ Sri Hidayati. Meningkatkan Kemampuan Mengenal Warna Melalui Kegiatan Mencampur Warna di TK Kehidupan Elfhaluy Tenggarong. Yaa Bunayya: Jurnal Pendidikan Anak Usia Dini. Vol. 4. No 1
} 
Fikri Nazarullail, Dwi Bagus Rendy A.P, Pengenalan Permainan Warna Melalui Konsep Senyawa Polar dan Non Polar

d. Proses kegiatan belajar anak usia dini harus diarahkan pada pengembangan potensi kecerdasan secara menyeluruh dan terpadu. ${ }^{16}$

Berdasarkan pernyataan tersebut, maka kegiatan pembelajaran seraya bermain dapat menjadi alternatif bagi guru agar proses stimulasi yang dilakukan kepada anak dapat berjalan dengan maksimal. Pengenalan konsep warna dan pencampuran warna dapat dilakukan dengan cara memasukkan eksperimen sederhana untuk mengenalkan warna dan pencampuran warna. Salah satu aktivitas belajar yang digemari oleh anak usia dini adalah mewarnai. Kegiatan mewarnai dapat menjadi media berekspres ianak, dengan memilih warna-warna yang sesuai dengan keinginannya yang mungkin akan berbeda dengan pilihan temannya yang lain. ${ }^{17}$ Berdasarkan hal tersebut, maka kegiatan mewarnai dapat di modifikasi untuk melakukan eksperimen dengan memanfaatkan benda cair yang berwarna.

Menurut Brewster (dalam sachary) warna secara umum dapat digolongkan kedalam tiga kelompok utama, yaitu: ${ }^{18}$

a. Warna primer (merah, biru, dan kuning).

b. Warna sekunder (warna hasil dari campuran seimbang antara warna primer, seperti warna ungu $=$ merah + biru, orange $=$ merah + kuning dan hijau= kuning + biru).

c. Warna tersier (warna hasil campuran warna sekunder).

${ }^{16}$ Yuliani Nuraini Sujiono. Konsep Dasar Pendidikan Anak Usia Dini. Jakarta: PT Indeks. 2012: 153

${ }^{17}$ Nani Husnaini. Kegiatan Mewarnai Sebagai Stimulasi Perkembangan Kognitif Anak Usia Dini. https://doi.org/10.19109/ra.v3i2.4477. 2019: 112-133

${ }^{18}$ Agus Sachary. Seni Rupa Dan Desain SMA Jilid 1. Bandung: Gelora Aksara Pratama. 2004: 65 


\section{Perkembangan Kognitif}

Kognitif atau yang sering dihubungkan dengan tingkatan kecerdasan (integensi) yang dimiliki oleh manusia adalah kemampuan proses berfikir seseorang terhadap suatu kejadian. ${ }^{19}$ Perkembangan kognitif pada anak dimaksudkan agar mampu mengeksplorasi lingkungan sekitarnya melalui indera yang dimilikinya.

Pada penelitian ini difokuskan untuk membentuk pengetahuan anak terkait perkembangan kognitif yang menekankan pada kemampuan sains anak secara sederhana. Sujiono menyatakan bahwa sains adalah suatu subyek bahasan yang berhubungan dengan bidang studi tentang kenyataaan atau fakta dari teori-teori yang mampu menjelaskan tentang fenomena alam. ${ }^{20}$

Menurut Bloom dalam Sujiono, tingkat perilaku kognitif anak terjadi melalui beberapa tingkatan yaitu: pengetahuan, pemahaman, penerapan, analisis, sintesis, dan evaluasi. ${ }^{21}$ Pada penelitian yang dilakukan, proses pembentukan kognitif pada anak hanya sebatas pada proses pengetahuan tentang pencampuran warna dengan senyawa polar dan non polar.

\section{Senyawa Polar dan Non polar}

Atom unsure membentuk molekul senyawa dengan berikatan satu sama lainnya. Ikatan tersebut dapat berupa ikatan kovalen yang terbentuk karena mempunyai pasangan elektron yang digunakan bersama. Terjadi pada unsur yang bersifat non logam dengan non logam. Elektron yang digunakan bersama itu ditarik oleh kedua inti atom yang berikatan, sehingga kedua atom itu menjadi saling terikat. Atom-atom yang berikatan

\footnotetext{
${ }^{19}$ Fikri Nazarullail. Permainan Tradisional (Ditinjau Dari Aspek Perkembangan Anak Usia Dini). Surabaya: Pondok Pesantren (Ponpes) Jagad 'Alimussirry. 2019: 18

20 lbid

21 Yani Nuraini Sujiono. Metode Pengembangan Kognitif. Jakarta: Universitas Terbuka.2007: 9.30
} 
Fikri Nazarullail, Dwi Bagus Rendy A.P, Pengenalan Permainan Warna Melalui Konsep Senyawa Polar dan Non Polar

secara kovalen akan menghasilkan molekul-molekul yang dapat bersifat polar atau non-polar.22

Kepolaran molekul ini dipengaruhi oleh kepolaran ikatan-ikatan kovalen di dalam molekul dan bentuk molekul. Bentuk molekul dapat diramalkan menggunakan teori domain elektron dan teori hibridisasi. Dalam suatu molekul juga bekerja suatu jenis gaya yang mempersatukan molekul yang satu dengan molekul yang lain yang disebut gaya antar molekul. ${ }^{23}$

Senyawa polar adalah senyawa yang terbentuk akibat adanya suatu ikatan antar elektron pada unsur-unsurnya. Hal ini terjadi karena unsur yang berikatan tersebut mempunyai nilai keelektronegatifitas yang berbeda. Ciri-ciri senyawa polar yaitu dapat larut dalam air dan pelarut polar lainnya, memiliki kutub positif (+) dan kutub negatif (-), akibat tidak meratanya distribusi electron, dan memilik ipasangan electron bebas (bila bentuk molekul diketahui) atau memiliki perbedaan keelektronegatifan. Contoh senyawa polar adalah air, alkohol, $\mathrm{HCl}, \mathrm{PCl}_{3}, \mathrm{H}_{2} \mathrm{O}$, dan $\mathrm{N}_{2} \mathrm{O}_{5}$.

Senyawa non polar adalah senyawa yang terbentuk akibat adanya suatu ikatan antar elektron pada unsur-unsur yang membentuknya. Hal ini terjadi karena unsur yang berikatan mempunyai nilai elektronegatifitas yang sama atau hampir sama. Ciri-ciri senyawa non polar adalah tidak larut dalam air dan pelarut polar lain, tidak memiliki kutub positif $(+)$ dan kutub negatif $(-)$, akibat meratanya distribusi electron, dan tidak memiliki pasangan electron bebas (bila bentuk molekul diketahui) atau keelektronegatifannya sama. Contoh senyawa non polar adalah minyak goreng, bensin, solar, oli, $\mathrm{Cl}_{2}, \mathrm{H}_{2}$, dan $\mathrm{N}_{2}$.

22 Witri Esa Kencana. Pengembangan Virtual Lab Berbasis Model Inquiry Learning pada Materi Senyawa Kovalen Polar dan Non polar untuk SMA. FKIP: Universitas Jambi. 2018 ${ }^{23}$ Binar Pertiwi. Pengembangan Lembar Kegiatan Siswa (LKS) Berorientasi Problem Based Learning pada Materi Senyawa Kovalen Polar dan Nonpolar untuk MelatihkanK eterampilan Berpikir Tingkat Tinggi. Unesa Journal of Chemical Education: Vol. 5, No. 2, pp. 2016: 182-190 


\section{TEMUAN DAN PEMBAHASAN}

Penelitian ini dilaksanakan secara luring di sekolah dengan menerapkan protokol yang ketat dengan mencuci tangan sebelum melaksanakan kegiatan dan menggunakan masker selama kegiatan berlangsung. Kegiatan ini dilaksanakan dengan metode bermain, metode demonstrasi, dan metode eksperimen. Pelaksanaan kegiatan pengenalan permainan warna dengan senyawa polar dan non polar ini dilaksanakan di RA Bakti Telang. Kecamatan Kamal, Kabupaten Bangkalan. Proses kegiatan tersebut dilaksanakan di ruang aula dengan melaksanakan protokol kesehatan. Jumlah anak yang berpartisipasi dalam kegiatan ini ada 17 anak dari kelas B dengan kategori usia 5-6 Tahun.

Kegiatan ini dilakukan untuk mengamati aktivitas anak dalam melakukan kegiatan bermain seraya belajar melalui kegiatan eksperimen dengan mencampurkan benda cair yang memiliki perbedaan warna. Bahan-bahan yang digunakan dalam aktivitas pengenalan permainan mengenal warna melalui konsep senyawa polar dan non polar adalah air, kertas krip sebagai pewarna air, minyak goreng, bahan bakar minyak yaitu pertamax dan pertalite, spirtus, fanta serta teh kemasan. Dari benda cair tersebut juga terdapat perbedaan jenis senyawa yang dapat menghasilkan pencampuran warna dan juga pencampuran senyawa. Seperti pada pencampuran benda cair yang dilakukan oleh anak yaitu minyak yang di campur dengan spirtus yang memiliki warna yang berbeda. Kedua benda tersebut tidak akan bercampur karena memiliki sifat senyawa yang berbeda sehingga terbentuk dua lapisan zat yaitu cairan minyak yang berwarna kuning berada di sisi bawah dan air berwarna ungu di sisi atas.

Berikut ini adalah hasil eksperimen yang dilakukan oleh anak dengan mencampurkan dua benda cair yaitu minyak dan spirtus: 
Fikri Nazarullail, Dwi Bagus Rendy A.P, Pengenalan Permainan Warna Melalui Konsep Senyawa Polar dan Non Polar

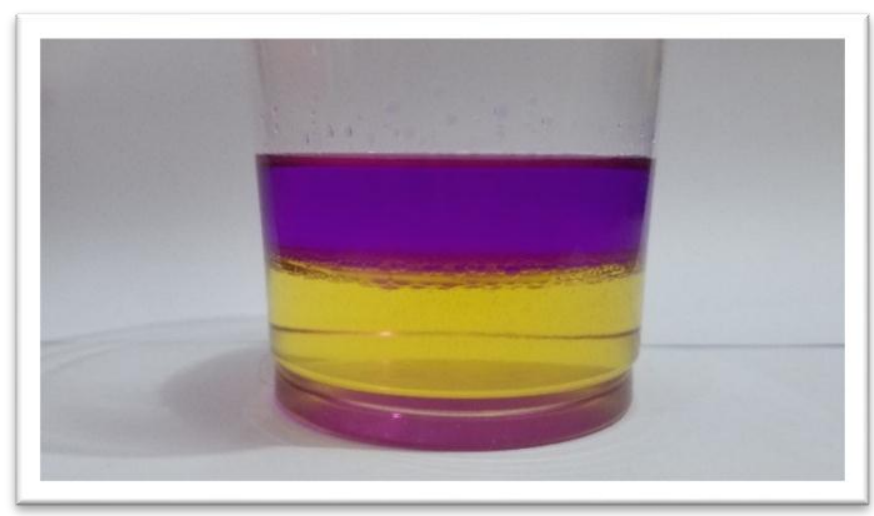

Gambar 1. Pencampuran Minyak dengan Spirtus

Berdasarkan gambar tersebut dapat diketahu ibahwa pengenalan warna berdasarkan benda cair yang dapat ditemukan di sekitar dipadukan dengan senyawa kimia polar dan non polar akan menghasilkan paduan warna yang berbeda lapisan. Konsep ini yang bisa menjadi inovasi dalam kegiatan pembelajaran dengan menerapkan konsep sains sederhana dengan warna-warna yang berbeda sehingga dapat menjadi kegiatan yang menarik dalam proses pembelajaran.

Pengenalan permainan mengenal warna melalui konsep senyawa polar dan non polar dilakukan dengan melakukan percobaan langsung atau eksperimen dengan secara langsung mengamati setiap aktivitas yang dilakukan anak. Peneliti mengembangkan angket untuk mengamati aktivitas mereka dengan sebelas butir pernyataan. Berdasarkan hasil obervasi yang dilaksanakan dengan melakukan penilaian ceklist pada tujuh belas anak dapat dilihat melalui diagram berikut:

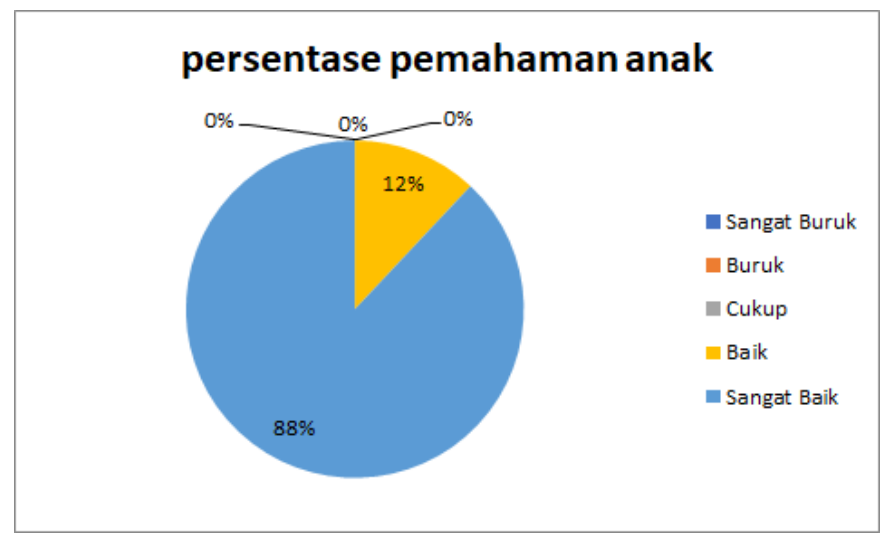

Gambar 2. Diagram Tingkat Pemahaman Anak 
Data pada diagram tersebut menunjukkan bahwa tingkat pemahaman anak tentang konsep pencampuran warna dengan senyawa polar dan polar memperlihatkan bahwa terdapat 88\% dengan jumah 15 anak yang memperoleh kategori sangat baik, dan 12\% dengan jumlah 2 anak memperoleh kategori nilai baik. Dan tidak ada anak yang memperoleh nila icukup, sedang atau buruk.

Berdasarkan data tersebut dapat di tarik kesimpulan bahwa kegiatan tentang pengenalan konsep pencampuran warna dengan senyawa polar dan polar memperoleh skor dengan kategori sangat baik, sehingga kegiatan dengan pola serupa dapat diaplikasikan di lembaga lain atau dapat mengadaptasi konsep sains sederhana lain dengan melakukan modifikasi dalam proses pelaksanaan kegiatannya sesuai dengan tahapan perkembangan anak usia dini.

\section{KESIMPULAN}

Perkembangan kognitif anak dapat distimulasi melalui berbagai macam cara yang dapat memberikan pengalaman baru kepada peserta didik dalam melaksanakan kegaiatan belajar dan pembelajaran di sekolah. Salah satu aktivitas yang di gemari oleh anak dalam kegiatan pembelajaran adalah melakukan aktivitas pencampuran warna. Dengan mengkombinasikan konsep pencampuran warna dengan konsep kepolaran senyawa kimia. Hasil dari penelitian ini mengatakan bahwa konsep kimia sederhana dapat diadaptasikan dalam proses belajar mengajar dengan mengenalkan senyawa polar dan non polar. Diharapkan dari adanya penelitian ini dapat menjadi motivasi bagi para pendidik pada jenjang pendidikan anak usia dini (PAUD) untuk dapat menerapkan konsep pencampuran warna dengan mengenalkan kimia sederhana senyawa polar dan non polar kepada anak. 
Fikri Nazarullail, Dwi Bagus Rendy A.P, Pengenalan Permainan Warna Melalui Konsep Senyawa Polar dan Non Polar

\section{DAFTAR PUSTAKA}

Amalia, Khairani. 2018. Meningkatkan kemampuan sains mengenal benda cair melalui metode eksperimen. Jurnal Ilmiah Potensia. Vol. 3 No. 2. https://ejournal.unib.ac.id/

Budiartati, Emmy. 2008. Pembelajaran melalui bermain berbasis kecerdasan jamak pada anak usia dini. Jurnal Lembaran IImu Pendidikan. Jilid 38 No 2. https://journal.unnes.ac.id/

Daryamti, Purwanti Suci Muji. Fitriani, \& Fadhilah, R. 2018. Pengembangan Lembar Kegiatan Peserta Didik (LKPD) Berbasis Predict-Observe-Explain (POE) pada Sub Materi Sifat Senyawa Ion dan Kovalen untuk Kelas X Farmasi SMK Panca Bhakti Sungai Raya. Ar-Razi Jurnal IImiah, 6(1), 98-108. http://open jurnal. unmuh pnk.ac.id/ index.php/ arr/article/ download/ 947/736

Hidayati, Sri. 2020. Meningkatkan Kemampuan Mengenal Warna Melalui KegiatanMencampur Warna Di TK Kehidupan Elfhaluy Tenggarong. Yaa Bunayya: Jurnal Pendidikan Anak Usia Dini. Vol. 4. No 1. https://jurnal.umj.ac.id/

Hurlock, Elizabeth. 1978. Perkembangan Anak. Jakarta: Erlangga.

Husnaini, Nani. 2019. Kegiatan Mewarnai Sebagai Stimulasi Perkembangan Kognitif Anak Usia Dini. Volume 3 No. 2. http://jurnal.raden fatah.ac.id/.

Kencana. Witri Esa. 2018. Pengembangan Virtual Lab Berbasis Model Inquiry Learning pada Materi Senyawa Kovalen Polar dan Non Polar untuk SMA. Skripsi (tidak diterbitkan). Jambi. FKIP: Universitas Jambi.

Kertamuda, Miftahun Achyar. 2015. Golden Age: Strategi Sukses Membentuk Karakter Emas Pada Anak Sejak Usia Dini. Jakarta: PT Gramedia.

Nazarullail, Fikri. 2019. Permainan Tradisional (Ditinjau Dari Aspek Perkembangan Anak Usia Dini). Surabaya: Pondok Pesantren (Ponpes) Jagad 'Alimussirry.

Pertiwi, Binar. 2016. Pengembangan Lembar KegiatanSiswa (LKS) Berorientasi Problem Based Learning pada Materi Senyawa Kovalen Polar dan Nonpolar untuk Melatihkan Keterampilan Berpikir Tingkat Tinggi. Unesa Journal of Chemical Education: Vol. 5. No. 2. p. $182-190$ 
Riduan. 2009. Dasar-dasar Statistika. Bandung: Alfabeta

Sachary, Agus. 2004. Seni Rupa dan Desain SMA Jilid 1. Bandung: Gelora Aksara Pratama.

Silalahi, Aamin. 2003. Metodologi Penelitian dan Studi Kasus. Jakarta: Citramedia.

Sujiono,Yuliani Nuraini. 2012. Konsep Dasar Pendidikan Anak Usia Dini. Jakarta: PT Indeks.

Susanto, Ahmad. 2014. Perkembangan Anak Usia Dini. Jakarta: 